\title{
THE INFLUENCE OF THE NASONOV PHEROMONE ON THE RECOGNITION OF HOUSE BEES AND FORAGERS BY VARROA JACOBSONI
}

\author{
Harald HOPPE and Wolfgang RITTER \\ Tierhygienisches Institut \\ Am Moosweiher 2, D-7800 Freiburg (FRG)
}

\begin{abstract}
SUMMARY
Simultaneous choice tests proved that Varroa jacobsoni is able to distinguish house bees and foragers by means of the age-dependent Nasonov pheromone production of the bees.

The secretion of one or 10 Nasonov glands, respectively, of foragers showed a repellent effect upon the mite equal to one or 10 bec equivalents, respectively, of geraniol, the main component of the pheromone.

One hundred bee equivalents of geraniol caused the strongest repellent effect.

Specimen gathered from 3 to 7 day old house bees did not show any influence on the mite in comparison to controls.

The results show that Varroa jacobsoni is capable of olfactorial recognition of house bees as ideal host.
\end{abstract}

\section{INTRODUCTION}

Varroa jacobsoni is not found in equal quantities on bees of any age. In comparison to old house bees and foragers, young nurse bees are more frequently parasited (Grobov, 1977 ; Kraus et al., 1986; Ritrer, 1981 ; ToschKoff et al., 1979). Apart from the frequency of being parasited there is also a difference in the location of mites on bees of different ages. In comparison to older bees, Varroa jacobsoni resides more frequently beneath the distal segments of the abdomen in young bees. In contrast, a higher percentage of mites is found between the thorax and abdomen in older bees.

Kraus et al. (1986) speculate that the mite can distinguish the age of bees by means of semiochemicals. The Nasonov pheronome is an odorous substance whose secretion depends on the age of the bees (Boch and Shearer, 1963 ; PicketT et al., 1981). 
We report the results of an investigation showing whether Varroa jacobsoni is able to distinguish the age of bees by means of the Nasonov pheromone and whether its main component, geraniol, is responsible.

\section{MATERIALS AND METHODS}

In order to determine the attractant or repellent effect of the Nasonov secretion and geraniol, simultaneous choice tests were made in the autumn of 1987. For these tests acrylic glass tubes were used having a length of $20 \mathrm{~cm}$ and a diameter of $4 \mathrm{~cm}$ (Fig. 1). One end of the tubes was closed with a miteproof wirenetting (width of meshes : $0.25 \mathrm{~mm}$ ), the other end with parafilm. A filter paper $(\varnothing 5 \mathrm{~mm})$ was pressed onto the center of the parafilm. The filter paper contained either the substance to be tested or the control solvent acetone.

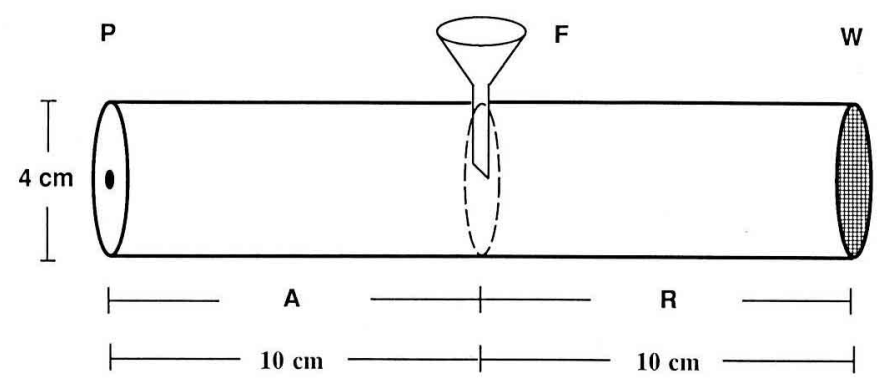

FIG. 1. - Experimental Design

$\mathrm{A}=$ Attractant field, $\mathrm{R}=$ Repellent ficld, parafilm with filter paper and test substance $(\mathrm{P})$, funnel for mite entry (F), mitc proof wirenctting (W).

Авв. 1. - Versuchaufbau

$A=$ Attractant-Feld, $\mathbf{R}=$ Repellent-Feld, Parafilm mit Filterpapier und Testsubstanz (P), Trichter zum Einfüllen der Milben (F), Milbendichtes Drahtgewebe (W).

For each replicate of the test about 30 Varroa mites (range : 25-32), collected from house bees were placed in the center of the tube divided into two sections. During the tests, the glass tube utilized was stored in a dark room at $20^{\circ} \mathrm{C}$. Thirty minutes later, the distribution of the mites in the tube was determined. The sector in front of the substance was defined as the attractant field, the one opposite to it as the repellent ficld. The pereentage of mites which frequented the repellent field was calculated and the results were studied statistically against controls, by means of the U-test.

In order to extract the Nasonov secretion the Nasonov glands were wiped with filter paper $(\varnothing 5 \mathrm{~mm})$ and then the paper was pressed upon the parafilm (RENNER, 1960). The secretion was taken from bees (Apis mellifera carnica Pollmann) either caught at the hive entrance or from 3-7 day old bees which emerged in an incubator and were kept at $25^{\circ} \mathrm{C}$. The amount secreted by one or 10 bees was examined.

Since absorption of the substance from 10 bees takes relatively long, a portion of the volatile ingredient may cvaporate. To avoid this, the substances of only 3 or 4 bees were put onto filter paper and fixed upon the parafilm at one time. The receptacle was then inverted onto the parafilm until the next sample was applied so that the pheromone could evaporate only into the tube. 
The effect of 3 different quantities of geraniol was tested : $0.1,0.01$ and $0.001 \mu$ geraniol (Carl Roth KG, $98 \%$ ) were dissolved in $10 \mu \mathrm{l}$ acetone and applied to the filter paper. After evaporation of the solvent, the paper was pressed upon the parafilm and used in the test tube. In the control tests, $10 \mu \mathrm{l}$ acetone were put upon the filter paper and, after evaporation, fixed in the same way.

\section{RESULTS AND DISCUSSION}

In controls with the solvent acetone in 22 tests an average of $54 \%$ of the mites were found in the repellent field (Tabl. 1). There was no significant difference to the equal distribution expected. As a consequence, the procedure proved to be suitable in demonstrating the influences of olfactory substances on the behavior of Varroa mites.

In the choice test more mites could be found in the repellent field when Nasonov secretion of one forager was used $(57 \%)$; the difference, however, was not significant $(\mathrm{z}=1.3)$. The difference was significant with the portions taken from 10 foragers $(76 \%, \mathrm{z}=2.8, \mathrm{P}<0.01)$. Therefore, the Nasonov secretion obtained from foragers has a strong repellent effect on Varroa mites. The Nasonov pheromone consists of $43 \%$ geraniol (PICKeTt et al., 1980). The secretion of one forager contains approximately $0.001 \mu \mathrm{l}$ geraniol.

Using the quantity of geraniol equivalent to the secretion of one bee, an average of $61 \%$ of the mites could be found in the repellent field; the difference, however, was not significant $(\mathrm{z}=1.4)$. In contrast, the average of $72 \%$ of the mites using 10 bee equivalents and $79 \%$ using 100 bee equivalents, were significant (Fig. 2). Consequently, both the Nasonov pheromone

TABL. 1. - Distribution of Varroa mites in tests of simultaneous choice Average number of mites in the repellent field expressed in percentage $(\overline{\mathrm{x}} \%)$, standard devia$\operatorname{tion}(\mathrm{s})$,

number of trials $(\mathrm{N})$, number of tested mites $(\mathrm{n})$, statistical examination against control (P)

TABL. 1. - Verteilung von Varroamilben im Simultanwahlversuch.

Durchschnittliche Anzahl der Milben im Repellentfeld in Prozent ( $\bar{x} \%)$, Standartabweichung(s),

Anzahl der Versuche (N), Gesamtzahl der Milben (n), Statistische Auswertung gegen die Kontrollversuche (P)

\section{Control}

Nasonov secret of 10 houses bees

Nasonov secret of one forager

Nasonov secret of 10 forager

$0.001 \mu l$ Geraniol

$0.01 \mu$ l Geraniol

$0.1 \mu l$ Geraniol

\begin{tabular}{|c|c|c|c|c|}
\hline$\tilde{\mathrm{x}}[\%]$ & S & $N$ & $\mathrm{n}$ & $\mathrm{P}$ \\
\hline 54 & 12 & 22 & 634 & \\
\hline 52 & 16 & 7 & 195 & $\mathrm{z}=0.3 \mathrm{n} . \mathrm{s}$ \\
\hline 57 & 18 & 9 & 258 & $\mathrm{z}=1.3 \mathrm{n} . \mathrm{s}$ \\
\hline 76 & 15 & 6 & 181 & $\mathrm{z}=2.8 \mathrm{p}<0.01$ \\
\hline 61 & 20 & 8 & 234 & $\mathrm{z}=1.4 \mathrm{n.s}$. \\
\hline 72 & 16 & 8 & 237 & $\mathrm{z}=2.7 \mathrm{p}<0.01$ \\
\hline 79 & 13 & 8 & 234 & $\mathrm{z}=3.4 \mathrm{p}<0.001$ \\
\hline
\end{tabular}




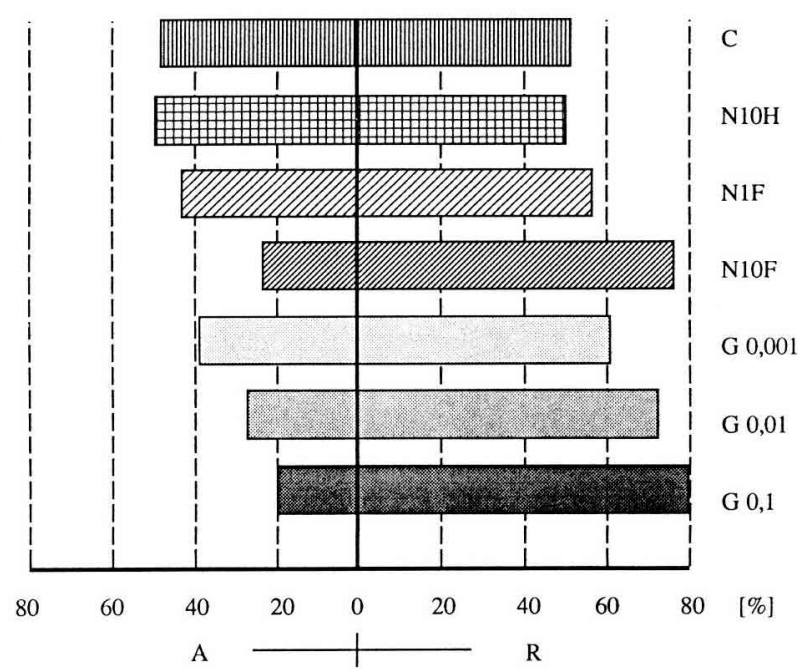

FIG. 2. - Distribution of Varroa mites in tests of simultaneous choice

$A=$ Attractant field, $R=$ Repellent field, Control $(C)$, Nasonov secret of 10 house becs $(\mathrm{N} 10 \mathrm{H})$, Nasonov secret of one forager (N1F), Nasonov secret of 10 foragers (N10F), $0,001 \mu$ l geraniol

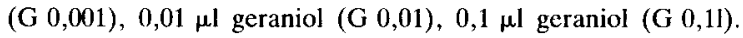

\section{Aвв. 2. - Verteilung von Varroamilben im Simultanwahlversuch}

$\mathrm{A}=$ Attractant-Feld, $\mathrm{R}=$ Repellent-Feld, Kontrolle (C), Nassonoff Sekret von 10 Stockbienen (N10H), Nassonoff Sekret von einer Flugbiene (N1F), Nassonoff Sekret von 10 Flugbienen (N10F),

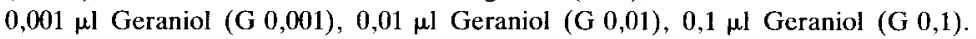

TABl. 2. - Statistical analysis. Control (C), Nasonov secret of 10 house bees (N10H), Nasonov secret of one forager (N1F), Nasonov secret of 10 foragers $(\mathrm{N} 10 \mathrm{~F}), 0.001 \mu \mathrm{l}$ geraniol (G 0.001),

$0.01 \mu l$ geraniol $(\mathrm{G} \mathrm{0.01)}, 0.1 \mu \mathrm{l}$ geraniol $(\mathrm{G} \mathrm{0.1)}$, not significant (n.s.), p $<0.05=*$,

$$
\mathrm{p}<0.01=* *
$$

TABL. 2. - Statistische Auswertung. Kontrolle (C), Nassonoff Sekret von 10 Stockbienen (N10H),

Nassonoff Sekret von einer Flugbiene (N1F), Nassonoff Sekret von 10 Flugbienen (N10F),

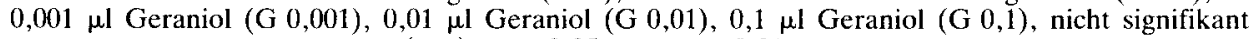
(n.s.), $\mathrm{p}<0,05=*, \mathrm{p}<0,01=* *$

\begin{tabular}{l|c|c|c|c|c|c}
\hline & $\mathrm{N} 10 \mathrm{H}$ & $\mathrm{N} 1 \mathrm{~F}$ & $\mathrm{~N} 10 \mathrm{~F}$ & $\mathrm{G} 0.001$ & $\mathrm{G} 0.01$ & $\mathrm{G} 0.1$ \\
\cline { 2 - 6 } C & n.s. & n.s. & $*$ & n.s. & $*$ & $* *$ \\
N10H & & n.s. & $*$ & n.s. & $*$ & $*$ \\
N1F & & & $*$ & n.s. & n.s. & $*$ \\
N10F & & & & n.s. & n.s. & n.s. \\
G 0.001 & & & & n.s. & $*$ \\
G 0.01 & & & & & & n.s. \\
\hline
\end{tabular}


taken from foragers and its main component, geraniol, possess a strong repellent effect on Varroa mites. The repellent effect is essentially due to geraniol (Tabl. 2).

House bees produce only very little Nasonov pheromone (ВосH and Shearer, 1963 ; Picketr et al., 1980). The filter paper used in wiping the Nasonov glands of the 3-7 day old bees did not show any repellent effect in the simultaneous choice tests in comparison to controls.

The strong repellent effect of the Nasonov secretion explains the favoured location of the mites on bees of different ages. Therefore, the mite is more frequently found between the head and thorax of older bees since they produce much secretion in the gland located on the penultimate segment of their abdomen. In nurse bees, however, it remains more frequently between the abdominal sternites.

In laboratory tests with bees infested by Varroa mites it is often observed that an increased number of mites fall off when the bees become excited. One symptom of excitement is the fanning of numerous bees accompanied by deposition of Nasonov pheromone.

Water carrying bees produce an especially large quantity of pheromone in order to mark water places (FrEe, 1968 ; FreE \& Williams, 1970) ; simultaneously, these bees are parasited least of all (HütTINGER et al., 1981).

The tests show that Nasonov pheromone possesses a strong repellent effect upon Varroa mites. By means of this substance Varroa jacobsoni is able to distinguish between house bees and foragers. Infestation of house bees is more advantageous for Varroa jacobsoni because they remain in the area of the brood nest, which is necessary for their reproduction. The Nasonov pheromone enables Varroa jacobsoni to always choose the ideal host.

It remains to be verified to which extent this substance or its main component, geraniol, can be utilized in the fight against Varroatosis.

Received for publication in January 1988. Accepted for publication in April 1988.

\section{RÉSUMÉ}

INFLUENCE DE LA PHÉROMONE DE NASONOV SUR LA RECONNAISSANCE DES ABEILLES D'INTÉRIEUR ET DES BUTINEUSES PAR VARROA JACOBSONI

Des tests de choix simultanés ont permis de montrer que Varroa jacobsoni peut distinguer les abeilles d'intéricur des butineuses par la phéromone de Nasonov, dont la production dépend de l'âge de l'abcille. 
Les tests ont été faits dans des tubes en plastique acrylique de $20 \mathrm{~cm}$ de long et de $4 \mathrm{~cm}$ de diamètre. L’une des extrêmités du tube était ferméc par un grillage ne laissant pas passer les acariens, l'autre extrémité par un parafilm. Un papier filtre contenant la substance à tester était fixé sur le parafilm. Pour chaque test on a placé environ 30 varroas au centre du tube divisé en deux sections. Après avoir laissé les tubes 30 minutes dans l'obscurité, on notait la distribution des acariens et calculait le pourcentage d'acariens présents dans le champ répulsif.

L'action répulsive due à la sécrétion produite par une glande et 10 glandes de Nasanov de butineuse a été respectivement de $57 \%$ et de $76 \%$. Un équivalent abcille et 10 équivalents abcille de géraniol, le composé principal de la phéromone, ont eu un effet répulsif comparable de $61 \%$ et $72 \%$ respectivement, sur Varroa jacobsoni. Cent équivalents abeille de géraniol ont produit l'effet répulsif le plus fort : $79 \%$. Des abeilles prélevées parmi des abeilles d'intérieur âgécs de 3 à 7 jours n'ont exercé aucunc action sur les acariens par rapport aux témoins.

La phéromone de Nasonov possède un effet répulsif puissant sur Varroa jacobsoni. Le composć principal, le géraniol, en est responsable. L'acarien peut reconnaître son hôte idéal, l'abeille d'intérieur, au moyen de cette substance odorante.

\section{ZUSAMMENFASSUNG}

\section{DER EINFLUSS DES NASSONOFF PHEROMONS AUF DAS ERKENNEN VON STOCK- UND TRACHTBIENEN DURCH VARROA JACOBSONI}

In Simultanwahlversuchen konnte gezeigt werden, daß Varroa jacobsoni mit Hilfe des altersabhängig produzierten Nassonoff Pheromons, Stock- und Flugbienen unterscheiden kann.

Die Versuche wurden in $20 \mathrm{~cm}$ langen Acrylglasrohren mit einem Durchmesser von $4 \mathrm{~cm}$ durchgeführt. Ein Ende der Rohre war mit milbendichtem Drahtgewebe, das andere mit Parafilm versehlossen. Ein Filterpapierstück, das dic Testsubstanz enthiclt, war auf dem Parafilm fixiert (Fig. 1). Bei jedem Versuch wurden etwa 30 Varroamilben in die Mitte des in zwei Abschnitte unterteilten Rohres eingesetzt. Nach 30 Minuten in der Dunkelheit wurde dic Verteilung der Milben bestimmt und der prozentuale Anteil der Versuchstiere im Repellentfeld errechnet.

Das Sekret von cincr bzw, 10 Nassonoff Drüsen von Flugbienen zcigte eine Repellentwirkung von $57 \%$ bzw. $76 \%$. Ein bzw. 10 Bienenequivalent Geraniol, der Hauptbestandteil des Pheromons, hatte cine vergleichbar stark abwehrende Wirkung auf Varroa jacobsoni mit $61 \%$ bzw. $72 \%$. 100 Biencnequivalent Geraniol verursachte mit $79 \%$ die stärkste Repellentwirkung. Sammelproben von zehn 3-7 Tage alten Stockbienen hatten im Vergleich zur Kontrolle keinen Einfluß auf die Milbe.

Nassonoff Pheromon hat eine starke Repellentwirkung auf Varroa jacobsoni. Der Hauptbestandteil, Geraniol, ist hierfür verantwortlich. Die Milbe kann mit Hilfe dieses Duftstoffes olfaktorisch ihren idealen Wirt, die Stockbiene, crkennen.

\section{REFERENCES}

Boch R., Shearer D.A., 1963. - Production of geraniol by honey bees of various ages. J. Insect Physiol., 9, 431-434.

FreE J.B., 1968. - The conditions under which foraging honey bees expose their Nasonov glands. J. apic. Res., 7, 142-147.

FreE J.B., Williams I.H., 1970, - Exposure of the Nasonov gland by honey bees (Apis mellifera) collecting water. Behaviour, 37, 286-290. 
Grobov O.F., 1977. - Varroasis in bees. In : Varroasis a honeybee disease. Apimondia Publishing House, Bukarest, 46-70.

Hüttinger E., Pechnacker H., Sulimanovic D. and Tomac I., 1981. - Zui Ausbreitung von Varroa jacobsoni Oud. von Volk zu Volk. In: Diagnose und Therapie der Varroatose. Apimondia-Vcrlag, Bukarest, 56-62.

Kraus B., Koeniger N., Fuchs S., 1986. - Unterschcidung zwischen Bienen verschiedenen Alters durch Varroa jacobsoni Oud. und Bevorzugung von Ammenbienen im Sommervolk. Apidologie, 17 (3), 257-266.

Picketi J.A., Williams 1.H., Martin A.P., Smith M.C., 1980. - Nasonov pheromone of the honey bee, Apis mellifera L. (Hymenoptera : Apidae). Part I. Chemical characterisation, J. Chem. Ecol., 6 (2), 425-434.

Pickett J.A., Williams I.H., Smith M.C., Martin A.P., 1981. - Nasonov pheromone of the honey bee, Apis mellifera L. (Hymenoptera, Apidae). Part III. Regulation of pheromone composition and production. J. Chem. Ecol., 7 (3). 543-554.

Renner M., 1960. - Das Duftorgan der Honigbiene und dic physiologische Bedeutung ihres Lockstoffes. Z. vergl. Physiol., 43, 411-468.

Ritter W., 1981, - Varroa disease of the honcy bec Apis mellifera. Bee World, 62 (4), 141-153.

Toschкoff A., 1979. - Neucs im Studium und der Bekämpfung der Varroatose. In : Bekämpfung und Vorbeugung der Varroatose. Apimondia-Publishing House, Bukarest, 32-35. 